\title{
The Different Effects on the Serum Lipids and Fecal Steroids of High Carbohydrate Diets Given Orally or Intravenously
}

\author{
Lawrence DenBesten, Roberto H. Reyna, William E. Connor, and \\ Lewis D. STEGiNK \\ From the Clinical Research Center and the Departments of Surgery, Internal \\ Medicine, and Pediatrics, University of Iowa College of Medicine, \\ Iowa City, Iowa 52242
}

A в S T R A C T The hypothesis that diets high in carbohydrate produce hyperlipidemia in man was tested in new experiments which provided all calories either by the intravenous route or orally. After a base-line general diet, eight healthy men were fed fat-free diets consisting of $80 \%$ of the calories from glucose and $20 \%$ from an amino acid hydrolysate. The calories were adequate to maintain body weight. The solutions $(1 \mathrm{cal} / \mathrm{ml})$ were infused by constant drip over a $24 \mathrm{~h}$ period through either a superior vena cava catheter or a nasogastric tube. Each feeding was for 12 days in sequence but assigned in random order.

The high $\mathrm{CHO}$ diet given orally, as expected, increased the mean base-line serum triglyceride level from $176 \pm 29$ (SE) to $274 \pm 47$. The identical diet given intravenously (i.v.) failed to produce hypertriglyceridemia; triglyceride levels were not significantly changed, 154士 37, nor were blood glucose levels. Serum insulin levels were higher during the intravenous feeding.

In contrast, both i.v. and oral feedings greatly lowered mean serum cholesterol concentration from the base-line value of $220 \pm 13 \mathrm{mg} / 100 \mathrm{ml}$ to $135 \pm 11$ and $151 \pm 13$, respectively. However, the serum cholesterol level was significantly lower $(P<0.01)$ with the intravenous feeding than with the oral feeding.

In addition, the fecal excretion of both neutral sterols and bile acids diminished greatly during the period of intravenous feeding. The fecal mass was likewise decreased. The bacterial conversion of cholesterol to coprostanol did not occur with either intravenous or oral feeding, but with both regimens secondary bile acids predominated, as usual, in the bile acid fraction of the stool.

This work was presented in part at the 1971 Annual Meeting of the Council on Arteriosclerosis of the American Heart Association.

Received for publication 9 November 1972 and in revised form 9 February 1973.
These results emphasize the key role of the intestinal mucosa in the etiology of carbohydrate-induced hypertriglyceridemia and as a direct or indirect contributor to plasma triglyceride and cholesterol levels in the absence of dietary lipids. When the gut mucosa was bypassed, carbohydrate-induced hypertriglyceridemia did not occur and both serum triglyceride and serum cholesterol levels decreased greatly at a time when the excretion of steroids in the stool was also reduced.

\section{INTRODUCTION}

The ingestion of a high carbohydrate diet produces acutely increased serum triglyceride levels in humans $(1,2)$. This response to increased dietary carbohydrate occurs invariably in normal and frequently in hypertriglyceridemic subjects $(3,4)$. In typical experiments, the sudden increase in dietary carbohydrate from 45 to $70-80 \%$ of the total calories (at the expense of dietary fat) usually doubles or triples serum triglyceride concentrations. The mechanism whereby this effect occurs has been postulated to be decreased removal of triglyceride by the peripheral tissues or increased triglyceride synthesis (5-8). Although the intestinal mucosa synthesizes both very low density lipoproteins $(9,10)$ and cholesterol $(11,12)$, most evidence has pointed to the liver as the site of the increased triglyceride synthesis resulting from a high carbohydrate diet $(3,7,13)$.

Recently, we observed that patients receiving their total caloric requirements by the intravenous feeding of a solution containing $80 \%$ of calories as glucose failed to have the expected elevation of serum triglycerides. This observation stimulated us to design experiments to compare the effects of high carbohydrate feeding on serum lipids and the sterol balance when identical high carbohydrate formulas were given intravenously and orally to the same subjects in sequential fashion. 
TABLE I

Description of Subjects

\begin{tabular}{ccccccc}
\hline $\begin{array}{c}\text { Sub- } \\
\text { jects }\end{array}$ & Age & Weight & Height & $\begin{array}{c}\text { Fasting } \\
\text { blood } \\
\text { sugar }\end{array}$ & $\begin{array}{c}\text { Serum } \\
\text { cholesterol }\end{array}$ & $\begin{array}{l}\text { Serum tri- } \\
\text { glycerides }\end{array}$ \\
\hline & & & & $m g / 100 m l$ & $m g / 100 m l$ & $m g / 100 ~ m l$ \\
1 & 40 & 222 & $6 \mathrm{ft} 1$ in & 83 & 166 & 165 \\
2 & 42 & 155 & $5 \mathrm{ft} 9$ in & 80 & 214 & 187 \\
3 & 40 & $169 *$ & $5 \mathrm{ft} 11$ in & 74 & 215 & 121 \\
4 & 33 & $227 *$ & $6 \mathrm{ft} 2$ in & 83 & 210 & 187 \\
5 & 36 & 130 & $5 \mathrm{ft} 7$ in & 75 & 201 & 51 \\
6 & 38 & 156 & $5 \mathrm{ft} 8$ in & 93 & 294 & 275 \\
7 & 42 & $173^{*}$ & $5 \mathrm{ft} 8$ in & 76 & 253 & 304 \\
8 & 32 & $165^{*}$ & $5 \mathrm{ft} 11$ in & 92 & 209 & 124 \\
\hline
\end{tabular}

* Period of nasogastric feeding preceded intravenous period.

\section{METHODS}

Eight healthy male volunteers from the Iowa State Penitentiary were admitted to the Clinical Research Center (Table I). All men had normal fasting and $2 \mathrm{~h}$ postprandial blood sugars. None were grossly obese. Base-line serum lipid analyses showed six men to have normal fasting serum cholesterol $(<210 \mathrm{mg} / 100 \mathrm{ml})$ and triglyceride $(<190 \mathrm{mg} / 100 \mathrm{ml}$ ) levels. Two men (subjects 6 and 7 ) were hyperlipidemic (cholesterol 294 and $253 \mathrm{mg} / 100 \mathrm{ml}$; triglycerides 275 and $304 \mathrm{mg} / 100 \mathrm{ml}$, respectively). Their lipoprotein electrophoretic strips indicated typical type IV (pre-beta) patterns.

A diet was selected which could be fed during both the intravenous and oral periods of the study (Table II). Of the total calories, $20 \%$ were derived from a casein amino acid hydrolysate (Amigen, Baxter Laboratories, Inc., Morton Grove, Ill.) and $80 \%$ from glucose. Appropriate electrolytes and vitamins were added to meet the daily nutritional requirements. Sterile solutions were prepared daily at a caloric equivalent of $1 \mathrm{cal} / \mathrm{ml}$. The total nitrogen content was 5.2 $\mathrm{g} /$ liter and the amino acid nitrogen was $3.12 \mathrm{~g} /$ liter. To minimize the effect of weight change on serum lipids, a careful dietary history was taken on admission to the Clinical Research Center and caloric needs were estimated from this information and from the height and weight. The men were ambulatory throughout the study and carried out usual ward recreational activities.

The experimental design of the study is shown in Table III. During the initial 7 day period, all subjects were fed a eucaloric (calories adequate to maintain body weight) general diet. During the next two 12 day sequential periods each subject was fed the eucaloric, fat- and cholesterol-free diet by either the nasogastric or intravenous routes. The solutions $(1 \mathrm{cal} / \mathrm{ml})$ were given as constant rate $24-\mathrm{h}$ infusions. Alternate pairs of subjects received their initial feeding either by the intravenous route or oral routes. During the final 7 day period a general diet was again fed. Two of the subjects were studied for a third 12 day period during which the experimental diet was fed by nasogastric catheter as four equal feedings instead of by continuous $24 \mathrm{~h}$ drip.

${ }^{1}$ The proposed study had been fully explained to each man and informed, written consent was obtained. The protocol of the study had been approved by the College of Medicine Research Committee in charge of all prison volunteer studies and by the Human Use Committee. The study was in accord with the principles of the Declaration of Helsinki.
TABLE II

Composition of the Nasogastric/Intravenous Diet (3,000 Cal)

$20 \%$ Casein hydrolysate ( $\%$ of calories)

$80 \%$ Dextrose

Electrolytes

Sodium

Potassium

Calcium

Chloride

Magnesium

Phosphate

Vitamins

Thiamine hydrochloride

Riboflavin

Sodium pantothenate

Niacinamide

Pyridoxine hydrochloride

Ascorbic acid

Phytonadione

Calorie content: $1 \mathrm{cal} / \mathrm{ml}$

$\begin{array}{rc}90 & \mathrm{meq} \\ 45 & \mathrm{meq} \\ 37 & \mathrm{meq} \\ 59 & \mathrm{meq} \\ 12.6 & \mathrm{meq} \\ 74 & \mathrm{meq} \\ & \\ 25 & \mathrm{mg} \\ 10 & \mathrm{mg} \\ 20 & \mathrm{mg} \\ 100 & \mathrm{mg} \\ 20 & \mathrm{mg} \\ 500 & \mathrm{mg} \\ 10 & \mathrm{mg}\end{array}$

The diet was given intravenously through a 17 gauge plastic catheter which had been threaded through the subclavian vein into the superior vena cava under fluoroscopic observation. All infusing solutions were passed through a 44 $\mu \mathrm{m}$ filter placed immediately proximal to the subclavian catheter. Every 3rd day all dressings were removed and skin around the catheter was defatted with acetone. The catheter tip was cultured at the termination of the study.

Each day at 8:00 a.m., the subjects were weighed and blood was ddrawn for cholesterol, triglyceride, lipoprotein electrophoresis, glucose, and serum insulin determinations. During the base line periods (initial and final) and the study periods in which the experimental diet was fed as meals, the subjects were fasted from 10:00 p.m. to 8:00 a.m. before blood specimens were obtained. All stools were collected and stored in plastic containers at $-20^{\circ} \mathrm{C}$ until analyzed.

The cholesterol content of serum was measured by the methods of Abell, Levy, Brodie, and Kendall (14). Serum triglycerides were determined fluorometrically using the Technicon Auto Analyzer (Technicon Instruments Corp., Tarrytown, N. Y.) following the method of Kessler and Lederer (15). Insulin levels in serum were quantified by the radioimmune assay method of Hales and Randle (16). Bile acid and neutral steroid excretion in feces were determined using previously described methods (17-19). All data

TABLE III

The Experimental Design of the Study Sequence of Dietary Periods

\begin{tabular}{llcc}
\hline $\begin{array}{c}\text { General } \\
\text { diet }\end{array}$ & \multicolumn{2}{c}{$\begin{array}{c}\text { Eucaloric, fat and cholesterol-free, } \\
\text { high carbohydrate diet }\end{array}$} & $\begin{array}{c}\text { General } \\
\text { diet }\end{array}$ \\
\hline Base line & $\begin{array}{c}\text { Period I } \\
\text { (nasogastric)* }\end{array}$ & $\begin{array}{c}\text { Period II } \\
\text { (intravenous)* } \\
12 \text { days }\end{array}$ & Base line \\
7 days & 12 days & days \\
\hline
\end{tabular}

* Order randomly assigned.

Serum Lipid and Fecal Steroid Studies 
TABLE IV

The Effect of the High Carbohydrate Diet and the Route of Administration upon the Serum Triglyceride Levels*

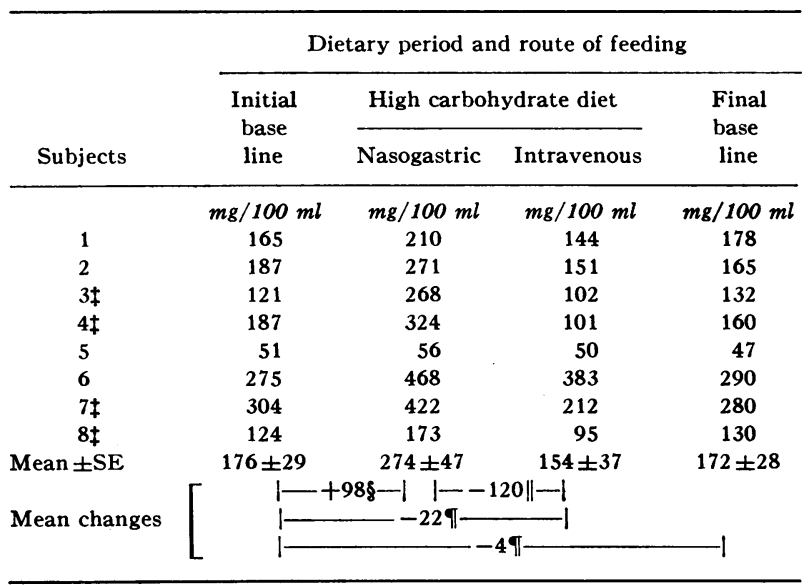

* Mean of last three determinations each period.

¥ Period of nasogastric feeding preceded intravenous period.

$\$ P<0.01$ (Student's $t$ test).

$\| P<0.005$.

II Not significantly different.

were expressed as the mean \pm standard error. Statistical comparisons of paired data were made by means of Student's $t$ test.

\section{RESULTS}

The mean serum triglyceride level increased significantly from the initial base-line value of $176 \mathrm{mg} / 100 \mathrm{ml}$ to 247 $\mathrm{mg} / 100 \mathrm{ml}$ when the high carbohydrate diet was fed by constant nasogastric drip (Table IV). With the administration of the high carbohydrate diet intravenously, the serum triglyceride concentration was $154 \mathrm{mg} / 100 \mathrm{ml}$, vastly different $(-120 \mathrm{mg} / 100 \mathrm{ml}, P<0.005)$ from that of the nasogastric feeding.

To determine the possible effect of the order in which the two different routes of administration were given, four subjects were fed the experimental diet intravenously first, followed by the nasogastric feeding (subjects 1, 2, $5,6)$. The order of entry into the study was exactly opposite in the remaining four subjects; that is, the nasogastric feeding preceded the intravenous feeding. One subject from each of these subgroups was hyperlipemic (subjects 6 and 7 with base-line serum triglycerides of 275 and $304 \mathrm{mg} / 100 \mathrm{ml}$, respectively). After the nasogastric feeding first, the serum triglyceride level increased from the mean base-line value of $184 \mathrm{mg} / 100$ $\mathrm{ml}$ in all four subjects to $297 \mathrm{mg} / 100 \mathrm{ml}$ and decreased in all subjects to $128 \mathrm{mg} / 100 \mathrm{ml}$ after the succeeding intravenous feeding (Table V). The four subjects who received the diet by the intravenous route during the first period of the study, followed by a period of constant drip feeding through a nasogastric tube, had an increase of serum triglycerides from a mean of $182 \mathrm{mg} / 100 \mathrm{ml}$ to 251 $\mathrm{mg} / 100 \mathrm{ml}$ (Table V).

Any changes in serum triglyceride concentration which followed the various diets began at $24 \mathrm{~h}$ and reached its maximum at $72 \mathrm{~h}$ where it plateaued until the end of the dietary period. With the nasogastric feeding, the serum triglyceride levels plateaued by $72 \mathrm{~h}$ and continued to be elevated for the remainder of the period. In contrast, during the intravenous feeding, the serum triglyceride levels remained essentially the same as during the base-line diet or else fell drastically (Table IV) from $274 \mathrm{mg} / 100 \mathrm{ml}$ to $154 \mathrm{mg} / 100 \mathrm{ml}$ in the switch from the nasogastric to the intravenous feeding.

TABLE V

The Effect of the Order in the Feeding Periods upon the Serum Lipid Concentrations and Body Weight

\begin{tabular}{llllc}
\hline & \multicolumn{3}{c}{ Nasogastric feeding period first (subjects 3, 4, 7, 8) } \\
\cline { 2 - 5 } & $\begin{array}{c}\text { Initial } \\
\text { base line* }\end{array}$ & Nasogastric & Intravenous & $\begin{array}{c}\text { Final } \\
\text { base line }\end{array}$ \\
\hline Triglyceride, $\mathrm{mg} / 100 \mathrm{ml}$ & $184 \pm 42.8$ & $297 \pm 52$ & $128 \pm 28$ & $176 \pm 36$ \\
Cholesterol, $m \mathrm{~g} / 100 \mathrm{ml}$ & $222 \pm 11$ & $164 \pm 14$ & $144 \pm 14$ & $208 \pm 8.3$ \\
Weight, $l b$ & $184 \pm 15$ & $184 \pm 14$ & $183 \pm 14$ & $184 \pm 14$ \\
\hline & Intravenous feeding period first (subjects $1,2,5,6)$ \\
\cline { 2 - 6 } & Initial & & & Final \\
base line & Intravenous & Nasogastric & base line \\
\hline Triglyceride, $m g / 100 m l$ & $169 \pm 46$ & $182 \pm 71$ & $251 \pm 85$ & $170 \pm 50$ \\
Cholesterol, $m g / 100 m l$ & $218 \pm 27$ & $127 \pm 19.7$ & $140 \pm 21$ & $202 \pm 23.2$ \\
Weight, $l b$ & $166 \pm 20$ & $166 \pm 19$ & $165 \pm 20$ & $168 \pm 21$ \\
\hline
\end{tabular}

* Data expressed as mean values $\pm \mathrm{SE}$.

1386 L. DenBesten, R. H. Reyna, W. E. Connor, and L. D. Stegink 
TABLE VI

The Effect of the High Carbohydrate Diet and the Route of Administration upon the Serum Cholesterol Levels*

\begin{tabular}{|c|c|c|c|c|}
\hline \multirow[b]{3}{*}{ Subjects } & \multicolumn{4}{|c|}{ Dietary period and route of feeding } \\
\hline & \multirow{2}{*}{$\begin{array}{l}\text { Initial } \\
\text { base line }\end{array}$} & \multicolumn{2}{|c|}{ High carbohydrate diet } & \multirow{2}{*}{$\begin{array}{c}\text { Final } \\
\text { base line }\end{array}$} \\
\hline & & Nasogastric & Intravenous & \\
\hline 1 & $\begin{array}{c}m g / 100 m l \\
166\end{array}$ & $\begin{array}{c}m g / 100 m l \\
119\end{array}$ & $\begin{array}{c}m g / 100 ~ m l \\
102\end{array}$ & $\begin{array}{c}m g / 100 m l \\
173\end{array}$ \\
\hline 2 & 214 & 157 & 147 & 222 \\
\hline $3 \ddagger$ & 215 & 196 & 161 & 215 \\
\hline $4 \ddagger$ & 210 & 131 & 105 & 190 \\
\hline 5 & 201 & 93 & 87 & 155 \\
\hline 6 & 294 & 189 & 172 & 257 \\
\hline $7 \ddagger$ & 253 & 178 & 165 & 227 \\
\hline $8 \ddagger$ & 209 & 150 & 144 & 198 \\
\hline $\begin{array}{l}\text { Mean } \pm \text { SE } \\
\text { Mean changes }\end{array}$ & $220 \pm 13.4$ & $\begin{array}{c}151 \pm 12.7 \\
698-1 \mid-85 \|-\end{array}$ & $\frac{135 \pm 11.5}{168-\mid}$ & $204 \pm 11.5$ \\
\hline
\end{tabular}

* Mean of last three determinations each period.

$\ddagger$ Period of nasogastric feeding preceded intravenous period.

$P<0.01$ (Student's $t$ test).

$\| P<0.001$.

I Not significant.

The serum cholesterol level dropped significantly from the base-line value of $220 \mathrm{mg} / 100 \mathrm{ml}$ during both the periods of intravenous and nasogastric feeding (Table VI). When the gut was completely bypassed by the intravenous route of nutrient administration, the serum cholesterol was lower than with oral feeding (151 to $135 \mathrm{mg} / 100 \mathrm{ml}$ ). Serum cholesterol levels were lower with the intravenous feeding irrespective of order of entry into the study protocol (Table V). The mean serum cholesterol level of the four subjects fed intravenously first was $127 \mathrm{mg} / 100 \mathrm{ml}$ and rose to $140 \mathrm{mg}$ / $100 \mathrm{ml}$ during the nasogastric period. Those fed by the nasogastric route for the first period had a mean cholesterol concentration of $164 \mathrm{mg} / 100 \mathrm{ml}$ which decreased to $144 \mathrm{mg} / 100 \mathrm{ml}$ after intravenous feeding.

During the final base-line dietary period (general diet), it was of interest that the serum triglyceride and cholesterol levels returned to the values of the initial base-line period (Tables IV and VI). For those subjects whose immediate preceding diet was the intravenous feeding, both serum cholesterol and triglyceride levels increased greatly (Table V). The subjects with an immediate preceding nasogastric feeding had a decline in the serum triglyceride concentration and a distinct rise in the serum cholesterol level as fat and cholesterol were again added to the diet.

Serum insulin and blood glucose determinations were carried out in all subjects at 8:00 a.m. on the 12th day of each intravenous constant feeding nasogastric period (Table VII). The mean serum insulin levels in all subjects during intravenous feeding were 101.5 \pm 43.0 and
TABLE VII

Serum Insulin and Glucose Concentrations on the 12th Day of Constant Nasogastric and Intravenous Feeding

\begin{tabular}{cccccc}
\hline & \multicolumn{2}{c}{ Nasogastric period } & & \multicolumn{2}{c}{ Intravenous period } \\
\cline { 2 - 3 } \cline { 5 - 6 } Subject & Insulin & Glucose & & Insulin & Glucose \\
\hline 1 & 38 & 116 & & 132 & 108 \\
2 & 32 & 120 & & 146 & 126 \\
3 & 21 & 95 & & 70 & 105 \\
4 & 39 & 105 & & 130 & 95 \\
5 & 76 & 98 & & 152 & 100 \\
6 & 32 & 130 & & 76 & 140 \\
7 & 28 & 120 & & 66 & 125 \\
8 & 32 & 105 & & 40 & 90 \\
$\bar{X} \pm$ SE & $37.3 \pm 16.6$ & $111.1 \pm 4.3$ & & $101.5 \pm 43.0^{*}$ & $111.1 \pm 6.2 \ddagger$
\end{tabular}

* Nasogastric vs. intravenous; $P<0.02$.

$\ddagger$ NS.

37.3 $\pm 16.6 \mu \mathrm{U} / \mathrm{ml}$ after nasogastric feeding, a greatly lower level $(P<0.02)$. Mean daily blood glucose concentrations for all subjects were $111.1 \pm 4.3 \mathrm{mg} / 100 \mathrm{ml}$ during constant nasogastric feeding and $111.1 \pm 6.2 \mathrm{mg} /$ $100 \mathrm{ml}$ during intravenous feeding. Serum insulin and glucose measurements were made in the last two subjects in the study on the 3rd, 8th 11th, and 12th day of each period (Table VIII). Again serum insulin levels were consistently lower when the diet was administered by the nasogastric route. At no time did glucosuria occur in any of the subjects. The weights of the individual subjects throughout the $5 \frac{1}{2}$ wk were constant.

Because we were concerned that the effect of the nasogastric feeding on serum triglycerides might only occur with constant nasogastric drip feeding over a $24 \mathrm{~h}$ period (i.e. analogous to "nibbling"), the final two subjects received the same formula diet in four equal feedings during a third 12 day period. One of these subjects was initially hypertriglyceridemic and the other had a normal serum triglyceride concentration. Neither serum triglyceride nor serum cholesterol level was different

TABLE VIII

Serum Insulin and Glucose Concentration in Two Subjects (Subjects 7 and 8) during Nasogastric and Intravenous Feeding

\begin{tabular}{|c|c|c|c|c|c|c|c|}
\hline \multirow{2}{*}{$\begin{array}{l}\text { Study } \\
\text { day }\end{array}$} & \multicolumn{3}{|c|}{ Nasogastric period } & \multicolumn{4}{|c|}{ Intravenous period } \\
\hline & Insulin & \multicolumn{2}{|c|}{ Glucose } & \multicolumn{2}{|c|}{ Insulin } & \multicolumn{2}{|c|}{ Glucose } \\
\hline & $\mu U / m l$ & \multicolumn{2}{|c|}{$\mathrm{mg} / 100 \mathrm{ml}$} & \multicolumn{2}{|c|}{$\mu U / m l$} & \multicolumn{2}{|c|}{$m g / 100 m l$} \\
\hline 3 & $78 * 38$ & 55 & 93 & 200 & 146 & 110 & 95 \\
\hline 8 & $32 \quad 34$ & 145 & 95 & 130 & 66 & 168 & 115 \\
\hline 11 & $30 \quad 20$ & 110 & 130 & 150 & 132 & 150 & 145 \\
\hline 12 & $28 \quad 32$ & 120 & 105 & 66 & 40 & 125 & 90 \\
\hline
\end{tabular}

* Data from subject 7 appears first in each column.

Serum Lipid and Fecal Steroid Studies 
TABLE IX

The Effects of the Nasogastric Feeding Given by a Constant 24 h Drip or as Four Meals

\begin{tabular}{ccc}
\hline & 24 h drip & Four meals* \\
\hline Serum triglyceride, $m g / 100 ~ m l$ & \\
Subject 7 & 296 & 297 \\
Subject 8 & 126 & 120 \\
Serum cholesterol, $m g / 100 m l$ & \\
Subject 7 & 182 & 186 \\
Subject 8 & 173 & 172 \\
\hline
\end{tabular}

* Values are fasting levels.

when the entire formula was fed in four meals in contrast to the $24 \mathrm{~h}$ drip (Table IX).

The quantity of stool diminished greatly during the period of eucaloric intravenous feeding as compared with the same feeding given by the nasogastric route: the mean stool weight being $21.4 \mathrm{~g} /$ day during the intravenous period and $74.4 \mathrm{~g} /$ day for the nasogastric period (Table $\mathrm{X}$ ). These data compare with usual mean stool weights of 50-94 $\mathrm{g}$ of patients receiving a formula diet containing $40 \%$ of the total calories as fat.

Correspondingly, the total fecal steroid excretion likewise decreased from $461 \mathrm{mg} /$ day to $205 \mathrm{mg}$ /day during the period of intravenous alimentation (Table X). Neutral steroid excretion declined from 283 to $160 \mathrm{mg} /$ day but the decrease in bile acid excretion was even more pronounced a change, from 178 to $45 \mathrm{mg} /$ day. In five of the eight subjects bile acid excretion was below 50 $\mathrm{mg} /$ day and in three subjects it was under $20 \mathrm{mg} /$ day.
The composition of the fecal neutral sterols for both routes of feeding was almost entirely cholesterol (Table $\mathrm{XI}$ ). The usual bacterially altered products of cholesterol in the feces, coprostanol and coprostanone, were virtually absent during the nasogastric feeding and greatly reduced or absent for the intravenous period. Bile acid excretion, especially low during the intravenous feeding, continued to be composed largely of the secondary bile acids, lithocholic and deoxycholic acids; $76 \%$ of the total bile acids after the intravenous feeding and $83 \%$ after the nasogastric route (Table XII).

\section{DISCUSSION}

Heretofore, the liver has been presumed to be the primary source of the hypertriglyceridemia in response to high dietary carbohydrate feeding by virtue of enhanced triglyceride synthesis $(3,7,13)$. The failure to produce hypertriglyceridemia in our experiments when the high carbohydrate diet was infused intravenously, thus bypassing the gut, suggests that the intestinal mucosa may have a prime role in the synthesis of triglyceride and lipoprotein resulting from a high carbohydrate diet. When the $80 \%$ carbohydrate diet was given orally, the mucosal absorption of glucose apparently stimulated triglyceride synthesis which then made a major contribution to the carbohydrate-induced hypertriglyceridemia.

The ingestion of a high carbohydrate diet is believed to elevate serum triglyceride levels by virtue of increased synthesis which results in an enlarged serum triglyceride pool (20). The increased rate of synthesis induced by carbohydrate feeding is apparently the same in normal subjects and in patients with known hypertriglyceri-

TABLE X

The Effect of the Route of Administration of the High Carbohydrate Diet upon the Fecal Mass and upon the Fecal Excretion of Neutral Sterols and Bile Acids

\begin{tabular}{|c|c|c|c|c|c|c|c|c|}
\hline \multirow[b]{3}{*}{ Subject } & \multicolumn{4}{|c|}{ Nasogastric period } & \multicolumn{4}{|c|}{ Intravenous period } \\
\hline & \multirow[b]{2}{*}{ Fecal mass } & \multicolumn{3}{|c|}{ Fecal steroid excretion } & \multicolumn{4}{|c|}{ Fecal steroid excretion } \\
\hline & & Neutral sterols & Bile acids & Total & Fecal mass & Neutral sterols & Bile acids & Total \\
\hline & $g / d a y$ & & $m g / d a y$ & & g/day & & $m g / d a y$ & \\
\hline 1 & 75.6 & 195 & 183 & 378 & 6.1 & 59 & 19 & 78 \\
\hline 2 & 75.7 & 190 & 150 & 340 & 37.5 & 216 & 61 & 277 \\
\hline 3 & 101.3 & 222 & 336 & 558 & 31.5 & 219 & 98 & 317 \\
\hline 4 & 68.0 & 235 & 179 & 414 & 8.6 & 170 & 14 & 184 \\
\hline 5 & 49.4 & 305 & 91 & 396 & 13.4 & 12 & 1 & 13 \\
\hline 6 & 89.2 & 215 & 92 & 307 & 31.5 & 227 & 126 & 353 \\
\hline 7 & 77.4 & 512 & 296 & 808 & 22.9 & 267 & 31 & 298 \\
\hline 8 & 58.7 & 393 & 96 & 489 & 19.4 & 108 & 10 & 118 \\
\hline $\bar{X} \pm \mathrm{SE}$ & $74.4 \pm 5.8^{*}$ & $283.4 \pm 40.5 \ddagger$ & $177.9 \pm 33.1 \S$ & $461.3 \pm 57.1 \ddagger$ & $21.4 \pm 4.1$ & $159.8 \pm 32.0$ & $45.0 \pm 16.2$ & $204.8 \pm 44.2$ \\
\hline
\end{tabular}

* $P<0.001$, Nasogastric vs. intravenous.

$\ddagger P<0.005$, Nasogastric vs. intravenous.

$\S P<0.05$, Nasogastric vs. intravenous.

1388 L. DenBesten, R. H. Reyna, W. E. Connor, and L. D. Stegink 
TABLE XI

Fecal Excretion of Cholesterol and Its Bacterial Degradation Derivatives during

Nasogastric and Intravenous Feeding

\begin{tabular}{cccccccc}
\hline & \multicolumn{3}{c}{ Nasogastric period } & & \multicolumn{3}{c}{ Intravenous period } \\
\cline { 2 - 3 } \cline { 6 - 7 } Subject & Cholesterol & $\begin{array}{c}\text { Coprostanol } \\
\text { +coprostanone }\end{array}$ & Total & & Cholesterol & $\begin{array}{c}\text { Coprostanol } \\
\text { +coprostanone }\end{array}$ & Total \\
\hline & & $m g /$ day & & & & mg/day & \\
1 & 195 & - & 195 & & 59 & - & 59 \\
2 & 190 & - & 190 & & 198 & 18 & 216 \\
3 & 222 & - & 222 & & 218 & 1 & 219 \\
4 & 235 & - & 235 & & 144 & 26 & 170 \\
5 & 305 & - & 305 & & 10 & 2 & 12 \\
6 & 210 & 5 & 215 & & 179 & 48 & 227 \\
7 & 509 & 3 & 512 & & 255 & 12 & 267 \\
8 & 393 & - & 393 & & 108 & - & 108 \\
$\bar{X} \pm$ SE & $281.1 \pm 39.9^{*}$ & & $283.4 \pm 40.5$ & & $146.4 \pm 29.4$ & & $159.8 \pm 32.0$ \\
\hline
\end{tabular}

* Nasogastric vs. intravenous, $P<0.02$.

demia (usually type IV hyperlipidemia). The greater pool size induced in the latter by a high carbohydrate feeding may result in part from a decreased rate of triglyceride removal by peripheral tissues. The significant finding in our experiments concerns the organ apparently responsible for increased triglyceride synthesis induced by carbohydrate feeding; i.e., the intestinal tract. All subjects, including two subjects who were initially hypertriglyceridemic, had decreased triglyceride levels when the intestine was bypassed by the intravenous feeding.

One alternative hypothesis might be that dietary carbohydrate, given orally, elevates serum triglycerides through a "gut" hormone or other factor which in turn acts to stimulate hepatic very low density lipopro- tein (VLDL) synthesis. Another hypothesis might be that oral dietary carbohydrate elevates serum triglyceride through a "gut" factor which acts to inhibit the removal of VLDL triglyceride.

Our hypothesis that the intestine may itself be responsible for increased triglyceride synthesis induced by carbohydrate conforms to the increasing recognition of the role of the intestinal mucosa in lipid synthesis. It has been found that significant triglyceride synthesis in the gut continues in triton-treated, hepatectomized rats (21) and in hepatectomized dogs (22). Ockner and Laster (11) and Baxter (10) found that $40 \%$ of the plasma triglyceride in the rat fed a fat-free diet was derived from intestinal lymph, a figure considerably higher than the $10 \%$ found by Windmueller and Levy

TABLE XII

The Fecal Excretion of Individual Bile Acids during Nasogastric and Intravenous Feeding

\begin{tabular}{|c|c|c|c|c|c|c|c|c|}
\hline \multirow[b]{2}{*}{ Subject } & \multicolumn{4}{|c|}{ Nasogastric period } & \multicolumn{4}{|c|}{ Intravenous period } \\
\hline & Lithocholic & Deoxycholic & Others & Total & Lithocholic & Deoxycholic & Others & Total \\
\hline & \multicolumn{4}{|c|}{$m g / d a y$} & \multicolumn{4}{|c|}{$m g / d a y$} \\
\hline 1 & 93 & 71 & 19 & 183 & 6 & 8 & 5 & 19 \\
\hline 2 & 44 & 51 & 55 & 150 & 28 & 10 & 23 & 61 \\
\hline 3 & 118 & 171 & 47 & 336 & 33 & 56 & 9 & 98 \\
\hline 4 & 57 & 97 & 25 & 179 & 7 & 1 & 6 & 14 \\
\hline 5 & 38 & 40 & 13 & 91 & 0.3 & - & 0.7 & 1 \\
\hline 6 & 52 & 33 & 7 & 92 & 58 & 49 & 19 & 126 \\
\hline 7 & 127 & 118 & 51 & 296 & 10 & 3 & 18 & 31 \\
\hline 8 & 29 & 45 & 22 & 96 & 1 & 2 & 7 & 10 \\
\hline $\bar{X} \pm \mathrm{SE}$ & $69.8 \pm 13.3^{*}$ & $78.2 \pm 16.9 \ddagger$ & $29.8 \pm 6.58$ & $177.9 \pm 33.1$ & $17.9 \pm 7.1$ & $16.1 \pm 8.0$ & $11.0 \pm 2.8$ & $45.0 \pm 16.1$ \\
\hline
\end{tabular}

* Nasogastric vs. intravenous, $P<0.005$.

$\ddagger$ Nasogastric vs intravenous, $P<0.01$.

$\$$ Nasogastric vs. intravenous, $P<0.02$. 
(23). This difference may be accounted for by the much lower hourly lymph triglyceride flow of $2.7 \mathrm{mg}$ observed by Windmueller as compared to a rate of $6 \mathrm{mg} / \mathrm{h}$ observed independently by Ockner and Baxter. Furthermore, very low density lipoprotein production has been observed in the intestinal mucosa of man and rat (24) and found in intestinal lymph under fasting conditions $(9,25)$. Low density (beta) lipoprotein synthesis also occurs in the rat intestinal mucosa $(23,26)$.

It is of interest that serum insulin levels in our subjects were generally higher during the continuous intravenous than during the oral feeding. Blood glucose values were similar. The higher insulin levels during the intravenous diet thus correlated inversely with the lower triglyceride concentrations occurring at the same time. These findings are in harmony with the overall hypothesis that insulin promotes the removal of triglyceride from the blood as recently reiterated by Barter, Carroll, and Nestel (27) who have extended the previous observations $(28,29)$ that serum insulin levels in human subjects fed a high carbohydrate diet show a highly significant inverse correlation with the serum triglyceride levels.

The mechanism by which insulin secretion was enhanced when the diet bypassed the gastrointestinal tract is unclear. Ordinarily, glucose alone stimulates more insulin release by the oral route vs. the intravenous route because of the release of various humoral factors (30). Plasma free amino acid levels are known to influence secretion of hormones by the endocrine glands, and may act as regulators for the secretion of insulin, glucagon, growth hormone, and the corticosteroids (31, 32). Studies using isolated pancreatic preparations in vitro $(33,34)$ and those using the intravenous administration of various amino acids indicate that elevated levels of certain amino acids in the plasma (particularly arginine, leucine, lysine, and possibly histidine) cause increased insulin secretion $(32,35-39)$. However, with the exception of an effect upon plasma cystine levels (40), few differences were noted in plasma amino acid levels in our subjects with the differing routes of alimentation. Plasma levels of the insulin-stimulating amino acids arginine, leucine, lysine, and histidine were nearly identical during the intravenous and oral feeding periods.

The absence of nutrients in the small intestine during the period of intravenous feeding undoubtedly decreased bile flow into the intestine. This hypothesis is suggested by, and would help to explain, the extremely low output of fecal bile acids when the gut was bypassed. Decreased enterohepatic circulation of bile would also result in decreased biliary lipid available in the intestinal lumen for triglyceride synthesis. The very small fecal mass during intravenous feeding may provide an index to the low metabolic activity of the intestinal mucosa when the gut was bypassed. Our experimental diet was obviously residue-free, so that the fecal mass would be entirely composed of the products of desquamated mucosal cells and bacteria.

If fatty acid for triglyceride synthesis by the intestinal mucosa is derived from bile phospholipid and the fatty acids of sloughed mucosal cells as reported by previous investigators $(9,10)$, then both decreased metabolic activity of the gut mucosa and the decreased bile flow would limit substrate for triglyceride synthesis. Fatty acid available for triglyceride synthesis may be further depleted by its use for the metabolic needs of the intestinal mucosa. Conversely, oral feeding of carbohydrate may provide a substitute source for fatty acid otherwise needed for intestinal metabolic needs; the fatty acid spared could then be used for triglyceride synthesis. Triglyceride synthesized in the intestinal wall is not thought to be derived from glucose carbons ( 5 , $6,10)$. Fatty acids from biliary phospholipid accounted for approximately $50 \%$ of the fatty acids in lymph triglyceride in fasting rats (10). Bile diversion with constant bile acid infusion resulted in a $60 \%$ fall from base line in intestinal lymph triglycerides (22). With total bile diversion, lymph lipid was further decreased (9, 41-43).

The use of a fat and cholesterol-free feeding during both of the experimental high carbohydrate dietary periods produced a sharp decline in serum cholesterol levels. These decreases are explainable on a twofold basis. Cholesterol was absent in the diet (44). Furthermore, even that cholesterol derived from the bile and the intestinal mucosa would have lessened absorbability because of the absence of dietary fat (45). These changes occurred with the oral feeding of the high carbohydrate diet at the same time that serum triglyceride concentrations were increasing some $50 \%$. Our assumption is that the decrease of cholesterol-rich beta lipoproteins more than compensated for the increase of very low density lipoproteins whose predominant lipid is triglyceride and which contain a much lower content of cholesterol.

The further lowering of the serum cholesterol level with the intravenous feeding probably occurred because the more metabolically quiescent intestinal mucosa was no longer contributing its customary amount of synthesized cholesterol to the plasma. It is of interest that this further $10 \%$ reduction of serum cholesterol matched the data of Dietschy and Wilson (46). They calculated that the intestinal mucosa contributes about $11 \%$ of the synthesized cholesterol entering the serum pool of cholesterol.

The much lower excretion of cholesterol in the stool during the intravenous feeding further corroborated the 
presumed low mucosa metabolic activity. We assume when no nutrients are entering the gastrointestinal tract that bile flow (and cholesterol excretion by this route) is at a minimum. Under this state of affairs most of the fecal cholesterol is probably derived from desquamated mucosal cells. The ratio of fecal bile acids to neutral sterols decreased during the intravenous feeding period. What cholesterol was present in the serum must have then been derived from hepatic synthesis.

The fecal neutral steroids are derived from three sources: unabsorbed dietary cholesterol, unreabsorbed bile cholesterol, and cholesterol secreted through the intestinal mucosa into the lumen and that contained in desquamated mucosal cells (47). In the present study, since cholesterol was absent in the diet, the fecal neutral steroids came from the latter two sources. An earlier study indicated that the bile flow decreased during fasting (48). In view of the fact that there was no food going through the gastrointestinal tract to stimulate normal digestive secretions and the low fecal bile acids excretion during the intravenous feeding period, it is probable that bile secretion was low during that period. Since the molar ratio of bile acid to cholesterol in the human bile is usually 12:1 (49) and since the fecal bile acid content was very low, it is likely that the contribution of bile cholesterol to the fecal neutral sterols was small during the intravenous feeding period. The fecal neutral steroids thus represented mainly that cholesterol derived from the desquamation of mucosal epithelium, or about $160 \mathrm{mg} /$ day. This value is slightly lower than the reported value measured in three patients with complete obstruction of biliary and pancreatic ducts (250-400 mg/day) (50). This may be due to a lower turnover rate of the mucosal cells in our normal subjects in the absence of the usual stimulation from the passage of nutrients through the intestinal tract. The excretion of both bile acids and neutral steroids was higher during the nasogastric than during the intravenous feeding period. Since the serum cholesterol in this period was also higher (151 mg/100 $\mathrm{ml}$ vs. $135 \mathrm{mg} / 100 \mathrm{ml}$ ), the larger secretion of fecal steroids can therefore be interpreted as the result of increased cholesterol synthesis in the mucosa and increased mucosal cell turnover.

Interestingly, the fecal steroids excretion during nasogastic feeding period was still lower than that of six normal subjects fed formula diets, cholesterol-free in our previous study (neutral steroid $388-419 \mathrm{mg} /$ day, bile acids $244-426 \mathrm{mg} /$ day) (19). The serum cholesterol of those subjects ranged from 177 to $226 \mathrm{mg} / 100 \mathrm{ml}$. The difference betwen nasogastric feeding and the previous formula feeding was that the fat content of the latter was $40 \%$ of the total calories. It is known that dietary fat stimulates the flow of bile $(20,51)$. The nasogastric feeding may have had the same effect as the intravenous feeding because of the low fat content. The movement of lipids from the liver may in turn stimulate the synthesis of cholesterol. It was reported that in the rat fed a cholesterol-free diet, dietary fat stimulated the removal of cholesterol from liver and increased cholesterol biosynthesis $(52,53)$.

A major fraction of fecal neutral steroids is usually excreted in the form of the saturated sterol, coprostanol $(54,55)$. In the feces of the eight subjects during both nasogastric and intravenous feeding periods, coprostanol was either completely absent or very low, from only 5 to $48 \mathrm{mg} /$ day. The virtual absence of bacterial activity for this sterol transformation may result from the character of the diet which was residue-free, fat-free, and cellulosefree. These constituents influence the bacteria flora and its metabolic activity. Phrenosin, which historically has been thought to influence the conversion of cholesterol to coprostanol, was also absent in the diet.

On the other hand, the percentage of the deoxycholic acid and lithocholic, secondary bile acids produced in the gut by bacterial action $(56,57)$, was $83 \%$ of total bile acid excretion for nasogastric feeding and $76 \%$ of total for intravenous feeding. These figures are comparable with a percentage of $87 \%$ usually found in human beings fed formula diets. This indicates that the activity of the bacteria responsible for the formation of secondary bile acids was not deterred by the experimental conditions of this study. It is not known what species of bacteria are responsible for these two different biochemical reactions in the colon (cholesterol and bile acid transformations).

\section{ACKNOWLEDGMENTS}

This work was supported by U. S. Public Health Service Research Grants HL-11,485 and HL-14,230 from the National Heart and Lung Institute, by the Clinical Research Center Grant M01-FR-59, by Research Career Development Award HL-K3-18,406 (Dr. Connor), by Corn Products International, and by the Iowa Heart Association.

\section{REFERENCES}

1. Hatch, F. T., L. L. Abell, and F. E. Kendall. 1955. Effects of restriction of dietary fat and cholesterol upon serum lipids and lipoproteins in patients with hypertension. Am. J. Med. 19: 48.

2. Ahrens, E. H., Jr., W. Insull, Jr., R. Blomstrand, J. Hirsch, T. T. Tsaltas, and M. L. Peterson. 1957. The influence of dietary fats on serum-lipid levels in man. Lancet. 1 : 943.

3. Waterhouse, C., J. H. Kemperman, and J. M. Stormont. 1964. Alterations in triglyceride metabolism as produced by dietary change. J. Lab. Clin. Med. 63: 605 .

4. Reaven, G. M., D. B. Hill, R. C. Gross, and J. W. Farquhar. 1965. Kinetics of triglyceride turnover of very low density lipoproteins of human plasma. J. Clin. Invest. 44: 1826.

5. Havel, R. J. 1968. Triglyceride and very low density lipoprotein turnover. In Proceedings of the 1968 Deuel Conference on Lipids. G. Cowgill, D. L. Estrich, and

Serum Lipid and Fecal Steroid Studies

1391 
P. D. Wood, editors. Superintendent of Documents, U. S. Government Printing Office, Washington, D. C. 117.

6. Sailer, S., F. Sandhofer, K. Bolzano, and H. Braunsteiner. 1970. Incorporation of plasma glucose carbon into plasma triglycerides in normal and patients with hypertriglyceridemia (Type IV). In Proceedings of the Second International Symposium on Atherosclerosis. Springer-Verlag New York Inc., New York. 277.

7. Quarfordt, S. H., A. Frank, D. N. Shames, M. Berman, and D. Steinberg. 1970. Very low density lipoprotein triglyceride transport in Type IV hyperlipoproteinemia and the effects of carbohydrate-rich diets. J. Clin. Invest. 49: 2281.

8. Havel, R. J., J. P. Kane, E. O. Balasse, N. Segel, and L. V. Basso. 1970. Splanchnic metabolism of free fatty acids and production of triglycerides of very low density lipoproteins in normotriglyceridemic and hypertriglyceridemic humans. J. Clin. Invest. 49: 2017.

9. Ockner, R. K., F. B. Hughes, and K. J. Isselbacher. 1969. Very low density lipoproteins in intestinal lymph: origin composition, and role in lipid transport in the fasting state. J. Clin. Invest. 48: 2079.

10. Baxter, J. H. 1966. Origin and characteristics of endogenous lipid in thoracic duct lymph in rat. J. Lipid Res. $7: 158$.

11. Ockner, R. K., and L. Laster. 1966. Biosynthesis of $\Delta 7$-cholesten- $3 \beta$-ol, $\Delta 5,7$-cholestadien-3 $\beta$-ol, and $\Delta 5$-cholesten- $3 \beta$-ol by guinea pig intestinal mucosa in vitro. J. Lipid Res. $7: 750$.

12. Wilson, J. D. 1968. Biosynthetic origin of serum cholesterol in the squirrel monkey: evidence for a contribution by the intestinal wall. J. Clin. Invest. 47: 175 .

13. Havel, R. J., and A. Goldfien. 1961. The role of the liver and of extrahepatic tissues in the transport and metabolism of fatty acids and triglycerides in the dog. J. Lipid Res. $2: 389$.

14. Abell, L. L., B. B. Levy, B. B. Brodie, and F. E. Kendall. 1952. Simplified method for estimation of total cholesterol in serum and demonstration of its specificity. J. Biol. Chem. 195 : 357.

15. Kessler, G., and H. Lederer. 1966. The fluorometric measurement of triglycerides-automation in analytical chemistry. In Technicon Symposia, 1965. L. T. Skeggs, Jr., editor. Mediad Inc., New York. 341.

16. Hales, C. N., and P. J. Randle. 1963. Immunoassay of insulin with insulin-antibody precipitate. Biochem. J. 88: 137.

17. Miettinen, T. A., E. H. Ahrens, Jr., and S. M. Grundy. 1965. Quantitative isolation and gas-liquid chromatographic analysis of total dietary and fecal neutral steroids. J. Lipid Res. $6: 411$.

18. Grundy, S. M., E. H. Ahrens, Jr., and T. A. Miettinen. 1965. Quantitative isolation and gas-liquid chromatographic analysis of total fecal bile acids. J. Lipid Res. 6: 397.

19. Connor, W. E., D. T. Witiak, D. B. Stone, and M. L. Armstrong. 1969. Cholesterol balance and fecal neutral steroid and bile acid excretion in normal men fed dietary fats of different fatty acid composition. J. Clin. Invest. 48: 1363 .

20. Taylor, C. B., and K. J. Ho. 1967. A review of human cholesterol metabolism. Arch. Pathol. 84: 3.

21. Byers, S. O., and M. Friedman. 1960. Site of origin of plasma triglyceride. Am. J. Physiol. 198: 629.
22. Roheim, P. S., L. I. Gidez, and H. A. Eder. 1966. Extrahepatic synthesis of lipoproteins of plasma and chyle: role of the intestine. J. Clin. Invest. 45: 297.

23. Windmueller, H. G., and R. I. Levy. 1968. Production of $\beta$-lipoprotein by intestine in the rat. J. Biol. Chem. 243: 4878.

24. Jones, A. L., and R. K. Ockner. 1971. An electron microscopic study of endogenous very low density lipoprotein production in the intestine of rat and man. $J$. Lipid Res. 12: 580.

25. Ockner, R. K., and A. L. Jones. 1970. An electron microscopic and functional study of very low density lipoproteins in intestinal lymph. J. Lipid Res. 11: 284.

26. Kessler, J. I., J. Stein, D. Dannacker, and P. Narcessian. 1970. Biosynthesis of low density lipoprotein by cellfree preparations of rat intestinal mucosa. J. Biol. Chem. $245: 5281$.

27. Barter, P. J., K. F. Carroll, and P. J. Nestel. 1971. Diurnal fluctuations in triglyceride, free fatty acids, and insulin during sucrose consumption and insulin infusion in man. J. Clin. Invest. 50: 583.

28. Berk, J. L., J. F. Hagen, W. H. Beyer, and M. J. Gerber. 1971. Hypoglycemia of shock. Ann. Surg. 171: 400 .

29. Engel, F. L., and J. E. White, Jr. 1960. Some hormonal influences on fat mobilization from adipose tissue. $\mathrm{Am}$. J. Clin. Nutr. 8: 691 .

30. Perley, M. J., and D. M. Kipnis. 1967. Plasma insulin responses to oral and intravenous glucose: studies in normal and diabetic subjects. J. Clin. Invest. 46: 1954.

31. Munroe, H. N. 1970. Free amino acid pools and their role in regulation. In Mammalian Protein Metabolism. $\mathrm{H}$. N. Munroe, editor. Academic Press, Inc., New York. 299.

32. Floyd, J. C., Jr., S. S. Fajans, J. W. Conn, R. F. Knopf, and J. Rull. 1966. Stimulation of insulin secretion by amino acids. J. Clin. Invest. 45: 1487.

33. Edgar, P., D. Rabinowitz, and T. J. Merimee. 1969. Effects of amino acids on insulin release from excised rabbit pancreas. Endocrinology. 84: 835.

34. Milner, R. D. G. 1969. Stimulation of insulin secretion in vitro by essential aminoacids. Lancet. 1: 1075.

35. Cochrane, W. A., W. W. Payne, M. J. Simpkiss, and L. I. Woolf. 1956. Familial hypoglycemia precipitated by amino acids. J. Clin. Invest. 35: 411.

36. Cremer, G. M., J. M. Bilstad, C. Faiman, and C. E. Moxness. 1968. Circulating levels of anterior pituitary hormones and insulin after arginine infusion. Mayo Clin. Proc. 43: 776.

37. Floyd, J. C., Jr., S. S. Fajans, J. W. Conn, R. F. Knopf, and J. A. Rull. 1966. Insulin secretion in response to protein ingestion. J. Clin. Invest. 45: 1479.

38. Fajans, S. S., J. C. Floyd, R. F. Knopf, and J. W. Conn. 1967. Effect of amino acids and proteins on insulin secretion in man. Recent Prog. Horm. Res. 23: 617.

39. Grasso, S., N. Saporito, A. Messina, and G. Reitano. 1968. Serum-insulin response to glucose and aminoacids in the premature infant. Lancet. 2: 755.

40. Stegink, L. D., and L. DenBesten. 1972. Synthesis of cysteine from methionine in normal adult subjects. Effect of route of alimentation. Science (Wash. D. C.). 178: 514.

41. Rony, H. R., B. Mortimer, and A. C. Ivy. 1933. The source of the lipids found in the thoracic duct lymph in fasting. Endogenous lipid secretion and reabsorption in the bowel. J. Biol. Chem. 102: 161. 
42. Pessoa, V. C., K. S. Kim, and A. C. Ivy. 1953. Fat absorption in absence of bile and pancreatic juice. $\mathrm{Am}$. J. Physiol. 174 : 209.

43. Shrivastava, B. K., T. G. Redgrave, and W. J. Simmonds. 1967. The source of endogenous lipid in the thoracic duct lymph of fasting rats. Q.J. Exp. Physiol. Cogn. Med.Sci. 52: 305.

44. Connor, W. E., R. E. Hodges, and R. E. Bleiler. 1961. The serum lipids in men receiving high cholesterol and cholesterol-free diets. J. Clin. Invest. 40: 894.

45. Esko, K., T. M. Lin, and A. C. Ivy. 1957. Capacity of human intestine to absorb exogenous cholesterol. $J$. Appl. Physiol. 11: 143.

46. Dietschy, J. M., and J. D. Wilson. 1970. Regulation of cholesterol metabolism. N. Engl. J. Med. 282: 1128, $1179,1241$.

47. Treadwell, C. R., and G. V. Vahouny. 1968. Cholesterol absorption. Handb. Physiol. 3 : 1407.

48. Okada, S. 1914. On the secretion of bile. J. Physiol. (Lond.). 49 : 457.

49. Taylor, W., editor. 1965. The Biliary System. A Symposium of the Nato Advanced Study Institute. 151.

50. Cheng, S. H., and M. M. Stanley. 1959. Secretion of cholesterol by intestinal mucosa in patients with com- plete common bile duct obstruction. Proc. Soc. Exp. Biol. Med. $101: 223$.

51. Swell, L., D. F. Flick, H. Field, Jr., and C. R. Treadwell. 1955. Role of fat and fatty acid in absorption of dietary cholesterol. Am. J. Physiol. 180: 124.

52. Alfin-Slater, R. B., M. C. Schotz, F. Shimoda, and H. J. Deuel, Jr. 1952. Effect of low fat and high fat diets on synthesis of cholesterol in rats. J. Biol. Chem. 195: 311.

53. Pihl, A. 1955. The effect of dietary fat on the intestinal cholesterol absorption and on the cholesterol metabolism in the liver of rats. Cholesterol studies. Acta Physiol. Scand. 34 : 183.

54. Rosenfeld, R. S., D. K. Fukushima, L. Hellman, and T. F. Gallagher. 1954. The transformation of cholesterol to coprostanol. J. Biol. Chem. 211: 301.

55. Rosenfeld, R. S., B. Zumoff, and L. Hellman. 1967. Conversion of cholesterol injected into man to cholesterol via 3-ketonic intermediate. J. Lipid Res. 8: 16.

56. Norman, A., and J. Sjövall. 1958. On the transformation and enterohepatic circulation of cholic acid in the rat: bile acids and steroids. J. Biol. Chem. 233: 872 .

57. Hill, M. J., and B. S. Drasar. 1968. Degradation of bile salts by human intestinal bacteria. Gut. 9: 22 . 